\title{
Evidence that changes in LH pulse frequency may regulate the seasonal modulation of $\mathrm{LH}$ secretion in ovariectomized mares
}

\author{
B. P. Fitzgerald, Helen I'Anson*, R. G. Loy and Sandra J. Legan* \\ Departments of Veterinary Science, and *Physiology \& Biophysics, University of Kentucky, \\ Lexington, Kentucky 40546-0076, U.S.A.
}

\begin{abstract}
Summary. To determine whether tonic LH secretion in ovariectomized mares is characterized by pulsatile release, frequent blood samples (every $15 \mathrm{~min}$ ) were collected from 5 ovariectomized horse mares in nine 8-h periods between February and May. Mean serum LH concentrations increased 9-fold and were associated with a 4-fold increase in mean LH pulse frequency. These results provide the first evidence of pulsatile $\mathrm{LH}$ release in ovariectomized mares and suggest that the increasing daylengths of the spring months may increase serum LH by increasing LH pulse frequency.
\end{abstract}

\section{Introduction}

In a wide variety of species, including man, sheep, rat, quail, deer and cattle, tonic LH secretion is characterized by brief, rhythmic episodes of release referred to as pulses (Yen, Tsai, Naftolin, Vandenberg \& Ajabor, 1972; Butler, Malven, Willett \& Bolt, 1972; Gay \& Sheth, 1972; Gledhill \& Follett, 1976; Lincoln \& Kay, 1979; Rahe, Owens, Fleeger, Newton \& Harms, 1980). The phenomenon of pulsatile release can be most easily detected in gonadectomized animals in which pulse frequency is maximal, because serum $\mathrm{LH}$ concentrations are elevated as a result of an absence of negative feedback (e.g. ewe and ram: see Karsch, 1980; Lincoln \& Short, 1980).

In ovariectomized Pony mares, in contrast to sheep and numerous other species, pulsatile LH release was not observed when blood samples were collected at 20-min intervals during a 4-h period (Garcia, Freedman \& Ginther, 1979). This observation could perhaps suggest a species difference. However, if LH pulse frequency varies over the time of day, as it does in Soay rams (Lincoln, Peet \& Cunningham, 1977), or if LH pulse frequency in ovariectomized Pony mares is less than once per $4 \mathrm{~h}$, then $\mathrm{LH}$ pulses might not be detectable by the above sampling regimen. Therefore, it remains to be determined whether tonic LH secretion in ovariectomized mares is pulsatile.

In several seasonal breeders (e.g. hares, ram, golden hamster, Djungarian hamster, sparrow), including Pony mares, tonic LH levels after gonadectomy are higher during stimulatory photoperiods than in the presence of inhibitory photoperiods (Davis \& Meyer, 1973; Pelletier \& Ortavant, 1975; Turek, Elliot, Alvis \& Menaker, 1975; Garcia \& Ginther, 1976; Mattocks, Farner \& Follett, 1976; Simpson, Follett \& Ellis, 1982). In rams, from which frequent blood samples can be collected over long periods, seasonal fluctuations in LH levels are associated with changes in the frequency of pulsatile LH discharge, such that pulse frequency is lowest during non-stimulatory daylengths when serum LH concentrations are low (Lincoln \& Short, 1980). This finding suggests that changes in LH pulse frequency are an important determinant of mean LH levels. 
The aims of the present study, therefore, were to investigate whether pulsatile $\mathrm{LH}$ release is a characteristic of tonic LH secretion in ovariectomized mares and, if so, to determine the relationship between the increasing daylengths of spring and the frequency of pulsatile LH discharge.

\section{Materials and Methods}

\section{Animals and collection of blood samples}

Five horse mares which had been ovariectomized 1 year previously were kept at pasture in Lexington (latitude $38^{\circ} 2^{\prime} \mathrm{N}$ ) and during each sampling period were housed in individual stalls under natural photoperiod and fed a small quantity of oats and hay. Water was always available.

On 9 occasions at approximately 2-week intervals between 3 February and 29 May 1982, each mare was brought into a stall and $2 \mathrm{~h}$ later fitted with an indwelling jugular venous catheter. The cannulae were maintained patent by flushing with saline $(9 \mathrm{~g} \mathrm{NaCl} / \mathrm{l})$ containing $5 \mathrm{i}$.u. heparin $/ \mathrm{ml}$.

Between 3 February and 30 April, blood $(5 \mathrm{ml})$ was withdrawn every $15 \mathrm{~min}$ for $8 \mathrm{~h}$ beginning at 10:00 h EST. During the 8-h sampling periods in May, the frequency of blood collection was increased to every $5 \mathrm{~min}$ for the first $2 \mathrm{~h}$ and then every $15 \mathrm{~min}$ for the next $6 \mathrm{~h}$. For each sample withdrawn the first 1 or $2 \mathrm{ml}$ were discarded and a further $5 \mathrm{ml}$ collected. Blood samples were allowed to clot at room temperature and incubated overnight at $4^{\circ} \mathrm{C}$. Serum was collected after centrifugation at $1600 \mathrm{~g}$ for $20 \mathrm{~min}$ and stored frozen until assayed for LH concentration.

\section{Radioimmunoassay of $\mathrm{LH}$}

The concentration of $\mathrm{LH}$ was estimated in serum using a radioimmunoassay procedure described previously (Loy, Evans, Pemstein \& Taylor, 1982). The antiserum (anti-ovine LH, GDN No. 15) was used at a final dilution of $1: 160000$ and routinely bound between 15 and $25 \%(\mathrm{~B} / \mathrm{Bo})$ of an iodinated, highly purified ovine LH preparation (LER 1056-C2), in the absence of competing hormone. Serum LH concentration was expressed in terms of an equine pituitary LH preparation, kindly supplied by Dr H. Papkoff. This LH has 2.97 times the activity of NIH-LH-S1 according to the ovarian ascorbic acid depletion assay (Licht et al., 1979). The sensitivity of the assay $(95 \%$ confidence limits of buffer controls) averaged $0.07 \mathrm{ng} / \mathrm{ml}$ and intra- and inter-assay coefficients of variation were 10 and $14 \%$, respectively, at $50 \%$ binding $(\mathrm{B} / \mathrm{Bo})$.

\section{Analysis of data}

The following criteria, modified from those of Goodman \& Karsch (1980), were employed to define an LH pulse: (1) a peak must occur within three samples of the previous nadir, (2) the amplitude of the pulse (peak concentration minus nadir) must be at least twice the sensitivity of the assay and (3) the LH level at the peak must exceed the $95 \%$ confidence limits of the concentration of LH at both the preceding and subsequent nadirs. The first criterion differs from that of Goodman \& Karsch (1980) in that the peak of the pulse must occur within 3 rather than 2 samples of the previous nadir. We have observed that after injection of gonadotrophin-releasing hormone, at a dose which elicits an LH pulse identical to that observed in ovariectomized mares in early April, the peak of the pulse frequently occurs within 3 samples obtained every $15 \mathrm{~min}$. The second criterion was modified to require that the amplitude of the pulse exceed twice, rather than once, the sensitivity of the assay to avoid interpreting low-amplitude fluctuations in LH levels as pulses.

Confidence limits for the LH concentration in each sample were determined by the method of Duddleson, Midgley \& Niswender (1972).

Statistical comparison of changes in LH pulse amplitude were made by a split-plot analysis of variance for repeated measurements. 


\section{Results}

A marked increase in mean \pm s.e.m. serum $\mathrm{LH}$ concentrations from $1.1 \pm 0.6 \mathrm{ng} / \mathrm{ml}(\mathrm{N}=5)$ to $9.6 \pm 0.6 \mathrm{ng} / \mathrm{ml}$ was observed between February and May (Text-fig. 1a). This dramatic 9-fold increase in circulating $\mathrm{LH}$ concentrations was mirrored by a coincident rise in LH pulse frequency from $0.4 \pm 0.4$ per $8 \mathrm{~h}$ in February to $4.4 \pm 0.8(\mathrm{~N}=5$ ) in early May (Text-fig. 1b). These coincident changes in serum LH concentrations and pulse frequency occurred when daylength was increasing (Text-fig. 1c).

A close inspection of the changes in serum LH concentrations in individual mares during February and March revealed that, in 4 mares, mean \pm s.e.m. serum LH concentrations decreased

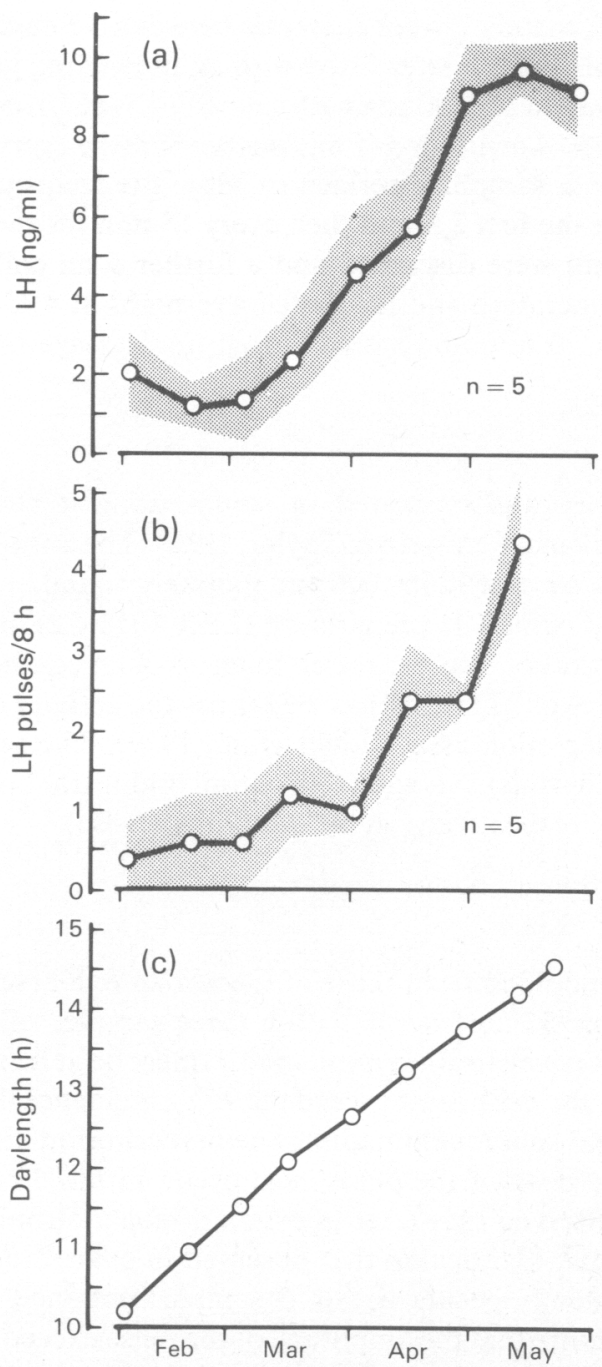

Text-fig. 1. Changes in mean ( \pm s.e.m.) serum LH concentrations (a) and mean LH pulse frequency (b) in 5 ovariectomized mares between February and May. The frequency of pulses in late May is omitted due to difficulties in detection of pulses at this time of year (see 'Discussion'). (c) Changes in daylength (latitude $38^{\circ} 2^{\prime} \mathrm{N}$ ). 


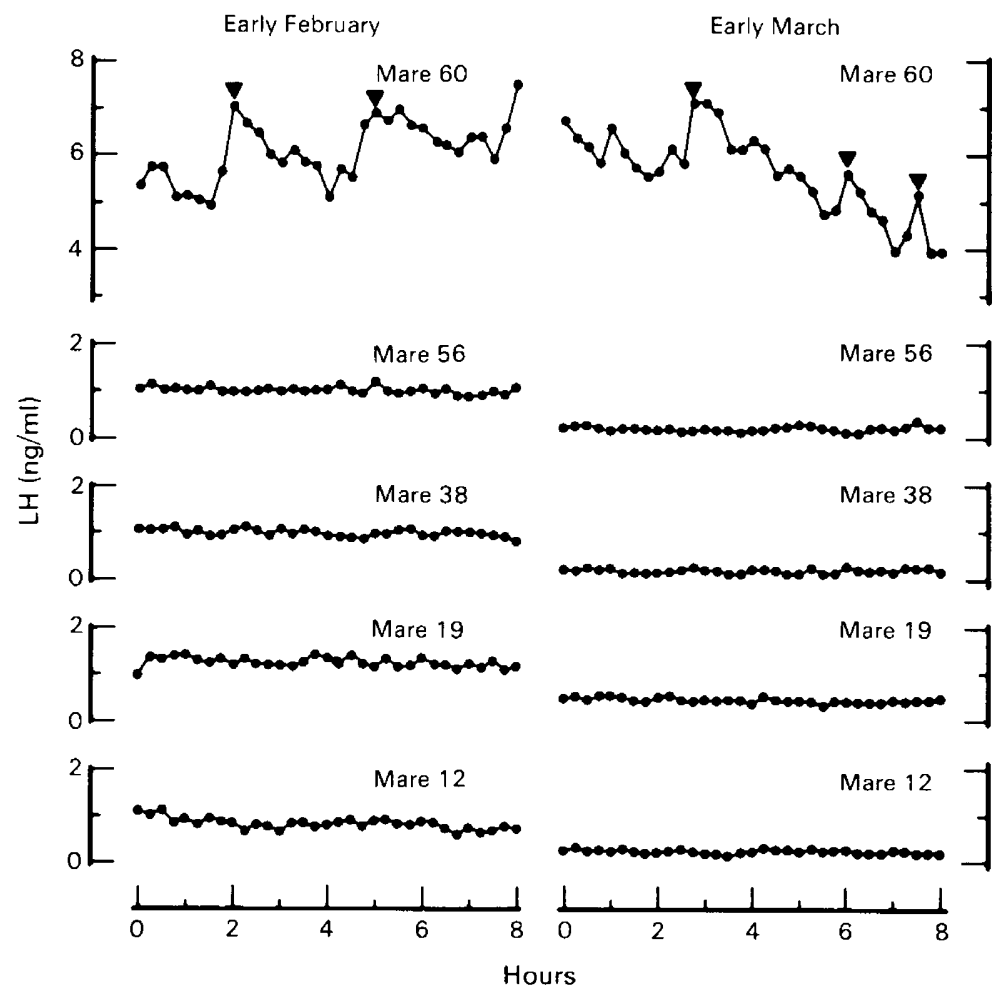

Text-fig. 2. Changes in serum LH concentrations in blood samples collected every $15 \mathrm{~min}$ during an 8-h sampling period from 5 ovariectomized mares in early February and early March. The occurrence of an LH pulse is indicated ( $\boldsymbol{\nabla})$ (see 'Materials and Methods' for criteria).

from $1.0 \pm 0.08 \mathrm{ng} / \mathrm{ml}$ in early February to a nadir of $0.2 \pm 0.06 \mathrm{ng} / \mathrm{ml}$ in early March and the pattern of secretion was not pulsatile (Text-fig. 2). However, there was evidence of an LH pulse in one of these mares (Mare 56, data not shown) during late February, since serum LH rose abruptly during the last $30 \mathrm{~min}$ of the $8-\mathrm{h}$ sampling period from 0.7 to $1.7 \mathrm{ng} / \mathrm{ml}$. In the fifth mare (Mare 60 ), although a decrease in serum LH was also observed, reaching a nadir in late February (data not shown), serum LH concentrations were consistently higher $(3-7 \mathrm{ng} / \mathrm{ml}$ ) and the pattern of release was clearly pulsatile. In each sampling period during February and March, pulse frequency in Mare 60 ranged between 2 and 3 per $8 \mathrm{~h}$. A rapid and pronounced increase in serum LH was associated with each pulse and the levels declined gradually thereafter to values equivalent to or below those observed before the pulse.

In the 4 mares in which the pattern of LH secretion was non-pulsatile during February and early March, the first evidence of LH pulses was observed in late March $(\mathrm{N}=2)$ or early April $(\mathrm{N}=2)$. A representative pattern of $\mathrm{LH}$ secretion from March to late April in one of these mares (Mare 12) is illustrated in Text-fig. 3. At the beginning of the 8-h sampling period in early April, serum $\mathrm{LH}$ concentrations averaged $0.7 \mathrm{mg} / \mathrm{ml}$ and were similar to values observed 2 weeks earlier (late March). After $2.5 \mathrm{~h}$, an LH pulse occurred, indicated by an abrupt increase in LH levels to $3 \mathrm{ng} / \mathrm{ml}$ and gradual decrease over the next $5 \mathrm{~h}$ to around $1 \mathrm{ng} / \mathrm{ml}$.

By mid-April, LH pulses were detected in all mares and the frequency in 3, including Mare 12, increased from 1 per $8 \mathrm{~h}$ in early April to 2 pulses per $8 \mathrm{~h}$. A close inspection of the pattern of $\mathrm{LH}$ secretion in Mare 12 revealed, however, that this may be an underestimate of the actual frequency 

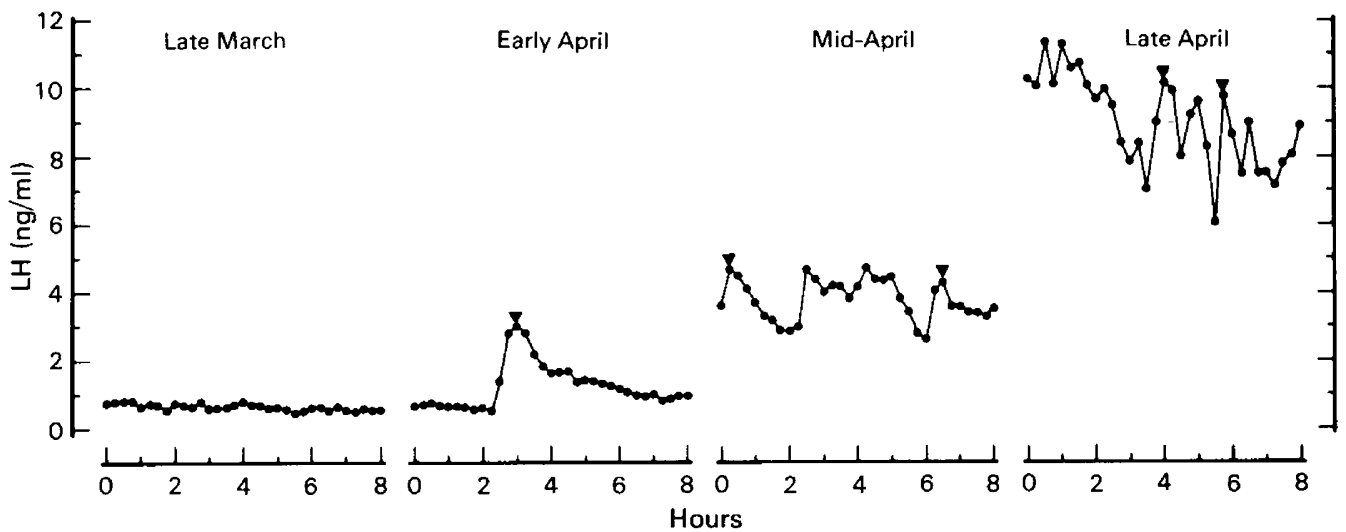

Text-fig. 3. Changes in serum $\mathrm{LH}$ concentrations in blood samples collected every $15 \mathrm{~min}$ during 8-h periods from Mare 12 between late March and late April. The occurrence of an LH pulse is indicated $(\boldsymbol{\nabla})$.

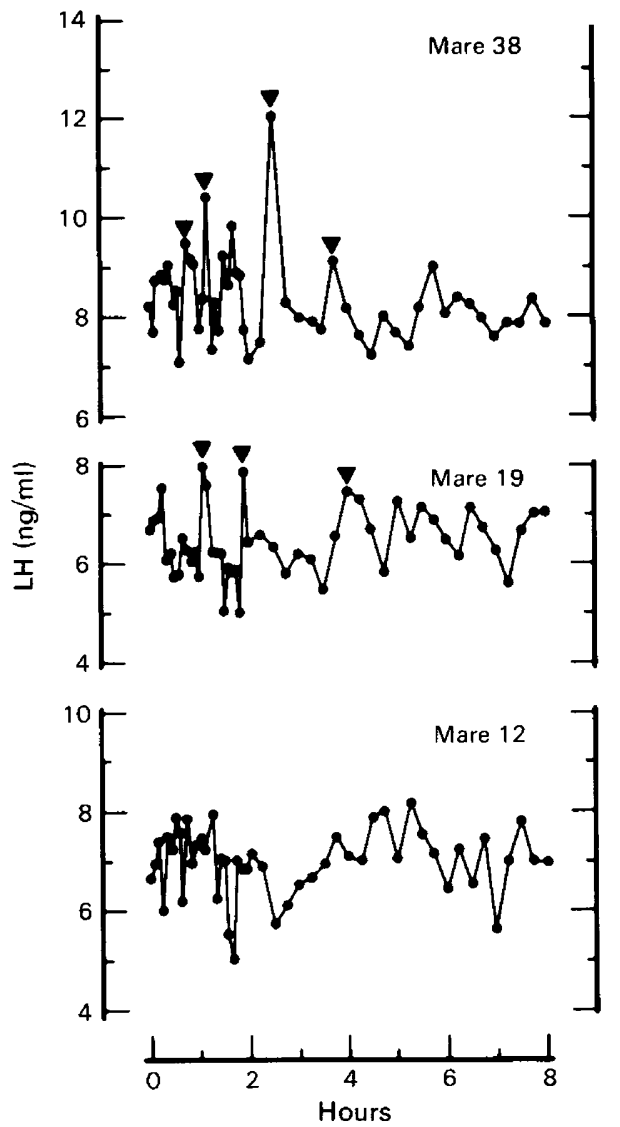

Text-fig. 4. Changes in serum LH concentrations in 3 ovariectomized mares during late May. Blood samples were collected every $5 \mathrm{~min}$ for the first $2 \mathrm{~h}$ and every $15 \mathrm{~min}$ for the next $6 \mathrm{~h}$. The occurrence of an LH pulse is indicated ( $\mathbf{\nabla})$. 
(Text-fig. 3). On this occasion 2 L.H pulses were observed, one at the start and the other at the end of the 8 -h period. In addition, at 2 and $4 \mathrm{~h}$ after the onset of the bleeding period, 2 abrupt increases suggestive of LH pulses were observed. Therefore, although 4 pulses may have occurred during this 8 -h period, only 2 were detected using the criteria selected.

Similar difficulties in identifying $\mathrm{LH}$ pulses were evident in all mares in the period between late April and late May. At this time of year, serum LH concentrations exhibited marked rapid fluctuations (Text-fig. 3, late April) and although the trend towards increasing pulse frequency continued in 4/5 mares during early May, the observed changes did not always permit an estimate of pulse frequency. Consequently, in 2 mares during late May, LH pulses could not be detected. As shown in Text-fig. 4, the more frequent collection of blood samples at 5-min intervals did not provide an improved estimate of either the occurrence of $\mathrm{LH}$ pulses or changes in frequency.

In the period between early April and late May, when the majority of mares were exhibiting pulsatile $\mathrm{LH}$ release, the mean \pm s.e.m. amplitude of the pulses tended to increase from $2.5 \pm 0.5$ $(\mathrm{N}=5)$ to $3.6 \pm 1.4 \mathrm{ng} / \mathrm{ml}(\mathrm{N}=22)$, but this increase was not significant $(P>0.05)$.

\section{Discussion}

The foregoing results demonstrate that an increase in mean serum LH concentrations is associated with increasing daylength. This finding confirms similar observations made on ovariectomized Pony mares (Garcia et al., 1979) and in numerous other gonadectomized seasonal breeders, in which exposure to stimulatory photoperiod increases LH levels (Davis \& Meyer, 1973; Pelletier \& Ortavant, 1975; Turek et al., 1975; Mattocks et al., 1976; Simpson et al., 1982). Although the maximal LH levels observed in the present study occurred in late May, serum LH concentrations may continue to increase throughout the summer. This possibility is supported by the observation that in ovariectomized Pony mares, which were sampled throughout the year, maximum LH concentrations were observed during September (Garcia et al., 1979).

The finding that photoperiod can modulate tonic LH levels in a variety of gonadectomized seasonal breeders, and that these seasonal fluctuations coincide with the onset and cessation of breeding activity in their intact counterparts (Davis \& Meyer, 1973; Turek et al., 1975; Mattocks et al., 1976; Garcia et al., 1979; Lincoln \& Short, 1980; Simpson et al., 1982), has led to the hypothesis that a gonadal-independent modulation of tonic LH secretion by photoperiod may have a role in the control of seasonal breeding (Lincoln \& Short, 1980). Alternatively, however, seasonal changes in photoperiod may modulate the negative feedback action of gonadal steroids on tonic gonadotrophin secretion, as described for the ewe and hamster (Legan, Karsch \& Foster, 1977; Turek \& Campbell, 1979). Our results support the former hypothesis, but the possibility that there is also a steroid-dependent action of photoperiod or that both photoperiodic mechanisms are operative in the control of seasonal breeding activity in the mare must be examined.

Although the long term changes in serum LH concentrations revealed in this study bear close resemblance to those described by Garcia et al. (1979), the present results extend their observations by providing the first unequivocal evidence of pulsatile LH release in the ovariectomized mare. Garcia et al. (1979) found no LH pulses in the summer in ovariectomized Pony mares sampled every $20 \mathrm{~min}$ for $4 \mathrm{~h}$. This lack of agreement between the two studies may be due to a difference in breed (Pony versus horse mares) or in season (summer versus winter and spring). A third possible explanation, however, is that in the summer, when mean serum LH levels are high in ovariectomized Pony mares, pulse frequency is too rapid to allow detection of discrete pulses in samples obtained every $20 \mathrm{~min}$. This latter possibility is supported by our observation that, in May, maximum mean LH concentrations are associated with rapid fluctuations and an accurate estimate of pulse frequency could not be determined in samples collected as often as every $5 \mathrm{~min}$, using the criteria selected. Finally, the discrepancy between the results of these 2 studies might be due to differences in the $\mathrm{LH}$ radioimmunoassays. In this regard, $\mathrm{LH}$ concentrations in the present study 
were determined using anti-ovine LH, whereas Garcia et al. (1979) used an antiserum to PMSG. Pulsatile LH release in 3 intact mares has been demonstrated using the anti-ovine LH (Evans, Hughes, Neely, Stabenfeldt \& Winger, 1979), whereas no pulses were detected in intact mares when the anti-PMSG serum was used (D. C. Sharp, personal communication).

The finding in the present study that, in $4 / 5$ mares, the first increase in serum $\mathrm{LH}$ concentrations coincided with the first detection of pulsatile $\mathrm{LH}$ release suggests that $\mathrm{LH}$ pulse frequency may be an important determinant of $\mathrm{LH}$ concentrations, as has been shown for rams (Lincoln \& Short, 1980). This suggestion is further strengthened by the fact that, in February, LH pulses were only observed in one mare in which serum LH concentrations were clearly higher than in the remaining mares. This relationship, however, is not always apparent since in some mares $\mathrm{LH}$ pulses were absent when LH concentrations reached near or maximal values (late May). Based on the observation that the collection of samples every $5 \mathrm{~min}$ revealed rapid fluctuations in $\mathrm{LH}$ concentration, it is possible that the criteria selected to define an $\mathrm{LH}$ pulse may have been inappropriate to detect the rapid pulse frequency which may occur when LH levels are high. The observation that elevated serum $\mathrm{LH}$ concentrations exhibited rapid fluctuations was an unexpected finding since it has been reported that the half-life of equine LH is about $1 \mathrm{~h}$ (Ginther, Pineda, Wentworth \& Nuti, 1974). At low serum LH concentrations, the time taken to return to basal values after an LH pulse appeared consistent with a slow clearance rate of about $1 \mathrm{~h}$. At the higher $\mathrm{LH}$ levels detected in late April and May, however, the half-life appeared to be decreased. Collectively, therefore, these observations suggest there may be a change in the metabolic clearance rate when LH concentrations increase. Alternatively, the apparent decrease in half-life might reflect secretion of a different $\mathrm{LH}$ form when $\mathrm{LH}$ concentrations reach maximum values. In this regard, Irvine (1979) has shown that equine pituitary LH is polymorphic, but it is not known whether different $\mathrm{LH}$ forms are present in the circulation.

In conclusion, the foregoing results provide the first evidence of pulsatile LH release in ovariectomized mares and, further, demonstrate that the long day-induced seasonal increase in serum LH levels from February to May is accompanied by an increase in LH pulse frequency.

The investigation reported in this paper (83-4-60) is in connection with a project of the Kentucky Agricultural Experiment Station and is published with approval of the Director. We thank the staff of the University Farm for the care of the animals; Dr T. Nett, Dr L. E. Reichert, Jr, Dr H. Papkoff and Dr L. Edgerton for RIA reagents; Ms S. Barrows for assistance with the RIAs. This work was supported in part by a grant from The Grayson Foundation, Inc. to R. G. L.

\section{References}

Butler, W.R., Malven, P.V., Willett, L.B. \& Bolt, D.J. (1972) Patterns of pituitary release and cranial output of $\mathrm{LH}$ and prolactin in ovariectomized ewes. Endocrinology 91, 793-801.

Davis, G.J. \& Meyer, R.K. (1973) Seasonal variation in LH and FSH of bilaterally castrated Snowshoe hares. Gen. comp. Endocr. 20, 61-68.

Duddleson, W.G., Midgley, A.R. \& Niswender, G.D. (1972) Computer program sequence for analysis and summary of radioimmunoassay data. Comp. Biomed. Res. 5, 205-217.

Evans, J.W., Hughes, J.P., Neely, D.P., Stabenfeldt, G.H. \& Winger, C.M. (1979) Episodic LH secretion patterns in the mare during the oestrous cycle. $J$. Reprod. Fert., Suppl. 27, 143-150.

Garcia, M.C. \& Ginther, O.J. (1976) Effects of ovariectomy and season on plasma luteinizing hormone in mares. Endocrinology 98, 958-962.
Garcia, M.C., Freedman, L.J. \& Ginther, O.J. (1979) Interaction of seasonal and ovarian factors in the regulation of $\mathrm{LH}$ and FSH secretion in the mare. $J$. Reprod. Fert., Suppl. 27, 103-111.

Gay, V.L. \& Sheth, N.A. (1972) Evidence for a periodic release of $\mathrm{LH}$ in castrated male and female rats. Endocrinology 90, 158-162.

Ginther, O.J., Pineda, M.H., Wentworth, B.C. \& Nuti, L. (1974) Rate of disappearance of exogenous $\mathrm{LH}$ from the blood in mares. J. Anim. Sci. 39, 397-403.

Gledhill, B. \& Follett, B.K. (1976) Diurnal variation and the episodic release of plasma gonadotrophins in Japanese quail during a photoperiodically induced gonadal cycle. J. Endocr. 71, 245-247.

Goodman, R.L. \& Karsch, F.J. (1980) Pulsatile secretion of luteinizing hormone: differential suppression by ovarian steroids. Endocrinology 107, 1286-1290. 
Irvine, C.H.G. (1979) Kinetics of gonadotrophins in the mare. J. Reprod. Fert., Suppl. 27, 131-141.

Karsch, F.J. (1980) Twenty-fifth annual Bowditch lecture. Seasonal breeding: a saga of reversible fertility. The Physiologist 23, 29-38.

Legan, S.J., Karsch, F.J. \& Foster, D.L. (1977) The endocrine control of seasonal reproductive function in the ewe: a marked change in the response to the negative feedback action of estradiol on luteinizing hormone secretion. Endocrinology 101, 818-824.

Licht, P., Bona Gallo, A., Aggarwal, B.B., Farmer, S.W., Castelino, J.B. \& Papkoff, H. (1979) Biological and binding activites of equine pituitary gonadotrophins and pregnant mare serum gonadotrophin. J. Endocr. 83, 311-322.

Lincoln, G.A. \& Kay, R.N.B. (1979) Effects of season on the secretion of LH and testosterone in intact and castrated red deer stags (Cervus elaphus). J. Reprod. Fert. 55, 75-80.

Lincoln, G.A. \& Short, R.V. (1980) Seasonal breeding: Nature's contraceptive. Recent Prog. Horm. Res. 36, $1-52$.

Lincoln, G.A., Peet, M.J. \& Cunningham, R.A. (1977) Seasonal and circadian changes in the episodic release of follicle-stimulating hormone, luteinizing hormone and testosterone in rams exposed to artificial photoperiods. J. Endocr. 72, 337-349.

Loy, R.G., Evans, M.J., Pemstein, R. \& Taylor, T.B. (1982) Effects of injected ovarian steroids on reproductive patterns and performance in post-partum mares. J. Reprod. Fert., Suppl. 32, 199-204.
Mattocks, P.W., Jr, Farner, D.S. \& Follett, B.K. (1976) The annual cycle in luteinizing hormone in the plasma of intact and castrated White-Crowned sparrows, Zonotrichia leucophrys gambelii. Gen. comp. Endocr. 30, 156-161.

Pelletier, J. \& Ortavant, R. (1975) Photoperiodic control of $\mathrm{LH}$ release in the ram. $\mathbf{I}$. Influence of increasing and decreasing light photoperiods. Acta endocr., Copenh. 78, 435-441.

Rahe, C.H., Owens, R.E., Fleeger, J.L., Newton, H.J. \& Harms, P.G. (1980) Pattern of plasma luteinizing hormone in the cyclic cow: dependence upon the period of the cycle. Endocrinology 107, 498-503.

Simpson, S.M., Follett, B.K. \& Ellis, D.H. (1982) Modulation by photoperiod of gonadotrophin secretion in intact and castrated Djungarian hamsters. $J$. Reprod. Fert. 66, 243-250.

Turek, F.W. \& Campbell, C.S. (1979) Photoperiodic regulation of neuroendocrine-gonadal activity. Biol. Reprod. 20, 32-50.

Turek, F.W., Elliot, J.A., Alvis, J.D. \& Menaker, M. (1975) The interaction of castration and photoperiod in the regulation of hypophyseal and serum gonadotropin levels in male golden hamsters. Endocrinology 96, 854-860.

Yen, S.S.C., Tsai, C.C., Naftolin, F., Vandenberg, G. \& Ajabor, L. (1972) Pulsatile patterns of gonadotropin release in subjects with and without ovarian function. J. clin. Endocr. Metab. 34, 671-675.

Received 21 April 1983 